\title{
Establishing Context to Build Capacity: A Qualitative Study to Determine the Feasibility, Utility, and Acceptability of a Complex Trauma Training for Psychologists Working in Urban Migrant Communities in Northern Peru
}

\author{
Brieanne K. Kohrt ${ }^{1} \cdot$ Maxwell P. Murray ${ }^{1} \cdot$ Lourdes Cabel Salinas $^{2}$
}

Received: 3 May 2019 / Accepted: 29 February 2020 / Published online: 10 March 2020

(c) Springer Science+Business Media, LLC, part of Springer Nature 2020

\begin{abstract}
Across Latin America, increasing access to mental health care has become a priority. Management of common mental disorders is shifting to primary care, and community mental health centers (CMHCs) are being established to treat severe needs. In urban migrant communities on the outskirts of Trujillo, Peru, five new CMHCs have been built to treat complex mental health concerns, partially in response to high rates of domestic violence and child maltreatment. However, psychologists have no training in the treatment of interpersonal trauma. This study sought to determine the utility of such a training and identify areas for cultural adaptation. Six focus groups were conducted with CMHC psychologists. Findings revealed that, while a culturally-adapted training in trauma-focused treatment is desired, sociocultural barriers to ensuring the physical and psychological safety of the service user must be considered, as well as provider barriers including short treatment packages, insufficient physical infrastructure, and unstable work conditions.
\end{abstract}

Keywords Capacity building $\cdot$ Peru $\cdot$ Complex trauma $\cdot$ Community mental health $\cdot$ Urban migrants $\cdot$ Global mental health

\section{Introduction}

Recent global mental health initiatives seeking to increase access to services in low-and-middle income countries (LMICs) have centered on shifting the identification and management of mild to moderate mental health problems to the primary health care (PHC) system, while communitybased psychologists take on a more supervisory and capacity building role. Simultaneously, the care of people with more complex and severe mental health problems is moving out of institutionalized settings and into community mental health

Brieanne K. Kohrt

Brieanne.kohrt@du.edu

Maxwell P. Murray

Maxwell.murray@du.edu

Lourdes Cabel Salinas

lourdescsalinas@gmail.com

1 The University of Denver, 2450 S Vine St, Denver, CO 80210, USA

2 Sayariy Resurgiendo, Urb Covicorti Condominio Tierra Verde, Bloque C 1102, Trujillo 13011, Peru as part of the deinstitutionalization of mental health care (Eaton et al. 2011; Kakuma et al. 2011; Patel et al. 2018). One such region making significant advances over the last decade in increasing access to mental health care is Andean South America (Pan American Health Organization 2013). Peru, for example, passed Law 29,889 in 2012, which sought to close the existing treatment gap (estimated at 70-85\% countrywide) by reducing psychiatric hospital beds, increasing the capacity of the PHC system to screen and treat common mental disorders, and establishing a community mental health center (CMHC) system. However, nearly $90 \%$ of the new mental health budget was dedicated to task-shifting at the PHC level, with limited finances remaining for training, development, and implementation at the CMHC level (Toyama et al. 2017). Capacity building initiatives are needed to help community-based psychologists develop skills in evidence-based practices (EBPs) to address complex mental health needs; without such efforts, a reduction in illness prevalence rate is unlikely (Jorm et al. 2017; Thornicroft et al. 2017).

The present study focuses on the advances and challenges of this new mental health paradigm in Trujillo, Peru, 
a northern coastal city with a population of approximately one million people. Forty percent of Trujillo's inhabitants are rural to urban migrants from the northern Andes who moved to the coast in search of work, education, or fleeing civil unrest associated with the Shining Path movement and government response. Migrants settled into shanty-town districts on the outskirts of the city (Naranjo Morales 2007); five of the six newly introduced CMHCs in Trujillo are in these districts. While this is promising for increasing access to mental health treatment, the psychologists serving these centers have not received training on the mental health needs of the migrant communities, which are marked by alarmingly high rates of familial violence and child maltreatment. Some of the highest documented rates of intimate partner violence (IPV) and sexual abuse in all of Latin America can be found in the Trujillo migrant communities (Kohrt BK et al. 2015). This region also reports high rates of child abuse, with nearly 11,000 cases reported in just one migrant district between 2007-2014 (Defensoría Municipal del Niño y el Adolescente de la Municipalidad Provincial de Trujillo 2014).

Despite these statistics, none of the local universities offer training in EBPs for trauma and have no resources for addressing interpersonal or complex trauma specifically (Quijano Pacheco 2017). Interpersonal trauma can be defined as a response to danger or threat of danger caused directly or indirectly by other people; examples include IPV, sexual abuse or assault, rape, and sex trafficking (Briere and Scott 2014). Complex trauma can be defined as exposure to multiple traumatic events of an invasive and interpersonal nature that results in emotional, behavioral, and interpersonal impairment (National Child Traumatic Stress Network 2018). Complex trauma often begins in childhood, is often perpetrated by caregivers or trusted adults, and significantly disrupts attachment relationships. This type of trauma has been linked to high rates of revictimization and self-harm behaviors, reduced productivity, functional impairment, and increased overall healthcare costs (Briere and Scott 2014). Attending to interpersonal trauma is imperative for the developmental potential of the next generation; a 2015 study conducted within one of the Trujillo migrant communities found a relationship between a mother's experience of IPV and impaired cognitive and psychosocial development in children (Kohrt BK et al. 2015).

Based on the psychosocial needs of the community, the impact of trauma on well-being, and the gaps in provider training, the goal of this study was to determine the utility, feasibility, and acceptability of a culturally and contextually adapted training in trauma-focused EBPs for communitybased psychologists. Trauma treatment has been studied at length, and there is significant literature on EBPs for complex and interpersonal trauma (e.g. Bisson et al. 2013; Bohus et al. 2013; Cusack et al. 2016; Foa et al. 2013; Gillies et al.
2013; Leenarts et al. 2013; Syros 2017). However, there are few studies on cultural adaptations of trauma-focused EBPs for the Latinx community, and no studies have been conducted in Latin America (Rivera 2008). Thus, prior to developing a training, the research team sought to: (1) understand the new CMHC system, (2) identify the type of trauma experienced by service users, (3) understand how trauma is defined and treated by local psychologists, and (4) identify sociocultural barriers to treatment that mitigate the use of certain therapeutic approaches.

\section{Methods}

\section{Research Design and Study Sample}

A qualitative focus group design was utilized with community-based psychologists in the target region. The primary author (BKK) and third author (LCS) contacted the Mental Health Department within the Ministry of Health in Trujillo, which oversees the CMHCs in each district. The research team's experience in the region was shared to develop trust and credibility; BKK is a clinical psychologist from the U.S. with ten years of experience working in the region, and LCS is a locally-trained psychologist from Trujillo with a background in community psychology. The Mental Health Department granted permission to recruit the psychologists for the study and expressed interest in a CMHC-wide training. Four regions in Northern Peru were targeted for the study: El Porvenir, Alto Trujillo, Florencia de Mora, and Viru. These regions have a high number of migrant families and are historically underserved by the government, with poor educational and health infrastructure (Naranjo Morales 2007). Four of the five CMHCs agreed to participate; the fifth was undergoing significant staff turnover and had no active psychologists. Given that one of the primary motivating factors for the training was related to high rates of IPV and child abuse, the only domestic violence center serving the urban migrant community and the one residential center for children removed from their home for reasons of neglect, abuse, or abandonment were also contacted and agreed to participate. Six focus groups were conducted with fifteen psychologists. Each mental health center comprised its own focus group, with two to four psychologists per group. Groups met on one occasion and lasted 45-90 min.

\section{Procedure}

Focus group meetings were conducted in Spanish by BKK and LCS. All psychologists interviewed were informed of the voluntary nature of participation and consented to being recorded for transcription purposes. The groups proceeded following a semi-structured focus group guide focused on: 
(1) the clinicians' role and responsibilities, (2) how clinicians defined trauma, including beliefs around recovery and the types of trauma seen in their centers, (3) their approach to treating trauma, and (4) previous trainings and barriers to implementation of training techniques and methods. Participants were invited to discuss unexplored topics they felt pertinent to the topic.

\section{Data Analysis}

Framework analysis (Parkinson et al. 2016) was used because of its utility in combining a priori issues and predefined themes with emergent data and unexpected findings. Framework analysis is especially useful for contextual research questions around the nature of what exists (for this study - what does trauma and recovery look like in these communities), diagnostic research questions (for this study - what are the potential causes for said trauma at the individual, community, and societal level), and evaluative research questions around the effectiveness of what exists (for this study, the effectiveness of the community mental health system and provider training in meeting the needs of service users with complex and interpersonal trauma).

The five stages of framework analysis were followed. In stage one (familiarization), two bilingual research assistants listened to the audio files, typed and read transcripts, and discussed emerging themes, which became the initial emergent codes. In stage two (identifying a framework), emergent codes were combined with a priori codes related to common elements of trauma-focused EBPs from the literature to create a coding framework. The resulting framework had 28 a priori and 22 emergent codes. In stage three (indexing) transcripts were uploaded into NVivo software and indexed by the research team using content coding methodology. Each transcript was coded by two researchers, and meetings were held to resolve any coding discrepancies. In stage four (charting) the data was organized by creating a summary of each category with key quotes attached. In stage five (mapping and interpretation) relationships between summary content were examined. Findings were also compared to the literature to determine fit and discrepancy. Materials remained in the source language, Spanish, throughout this process.

\section{Results}

Primary themes derived from the focus groups and subsequent analyses are summarized below. An anonymized participant code has been included with each quote. Quotes are provided in both English and Spanish to retain subtle changes in meaning inherent to the translation process.

\section{Mental Health Treatment Structure}

Based on interviews, the CMHCs follow a similar mental health structure (see Fig. 1). Notably, only one of the four sites had all four psychology positions filled. Potential clients meet with a nurse who does a standardized intake and categorizes their needs into one of four problem areas, each of which has an accompanying government-insured treatment package (see Table 1). All packages include psychiatric consultation. After the treatment package is completed, the client is moved to follow-up care, which includes monthly check-ins and optional workshops.
Fig. 1 Structure of the community mental health center (CMHC) system in La Libertad, Peru

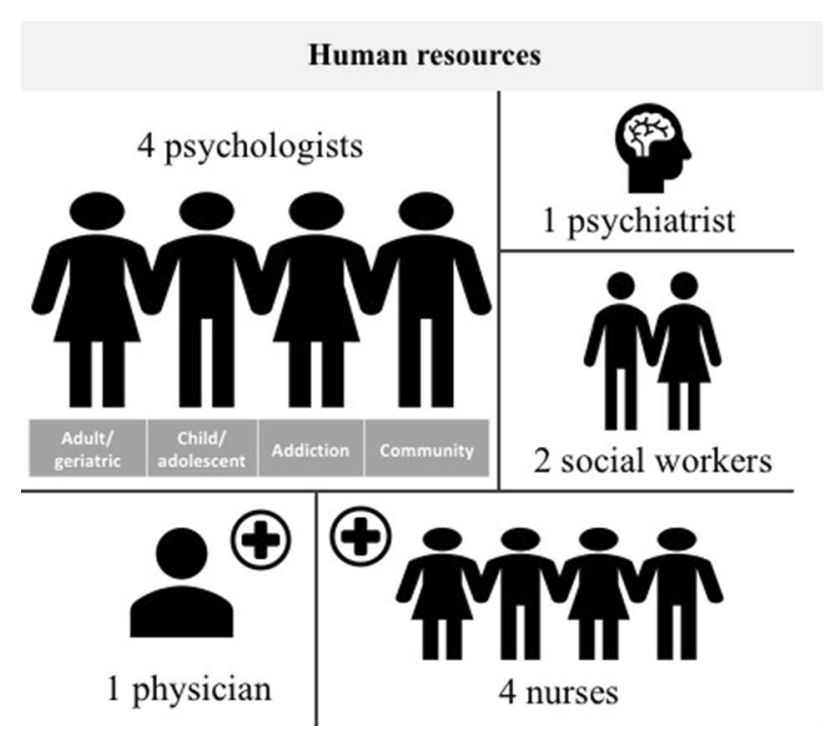

\section{Treatment path}

1. Meet with nurses for initial intake ( 1 session)

2. Doctor does medical exam to rule out medical causes ( 1 session)

3. Nurse determines diagnosis, provides psychoeducation regarding diagnosis to service user, assigns case to appropriate psychologists

4. Psychologist provides package of psychotherapy (4-10 sessions unless SMI), refers to psychiatrist as needed

5. Social workers conduct 1 home visit with all clients, additional home visits for SMI as needed. 
Table 1 Packages of care in the community mental health centers

\begin{tabular}{llll}
\hline Treatment area & Therapy sessions & $\begin{array}{l}\text { Medical } \\
\text { consult }\end{array}$ & Home visits \\
\hline 1: Violence and maltreatment & 5 & 1 & 1 \\
2: Depression, anxiety, and behavior disorders & 4 & 1 & 1 \\
3: Addiction & 10 & 1 & 5 \\
4: Schizophrenia, psychosis, other SMI & Unlimited & 5 & Unlimited \\
\hline
\end{tabular}

\section{Understanding of Trauma and Impact on the Service User}

Every psychologist reported seeing trauma cases regardless of their designated role and the client's presenting diagnoses since trauma does not conceptually fit any of the treatment packages. Overall, the psychologists defined trauma as coming from a painful event that is often unexpected, that the event changes a person's attitude about life, becomes a central feature of their identity, and results in pervasive feelings of self-blame, fear, and concern that the trauma will happen again, all of which significantly affect basic functioning. All focus groups highlighted how nearly all service users have experienced a trauma, with most traumas starting in childhood and being interpersonal in nature, such as physical, verbal, or sexual abuse, neglect, and forced labor. The most frequent words mentioned were abuse, sexual, physical, child, father, infancy, assault, neglect, and disasters. Grandfather, uncle, stepfather, and neighbor were also mentioned frequently. Cycles of violence and intergenerational trauma were mentioned by more than half of participants, as exemplified by Psychologist 11:

\begin{tabular}{|c|c|}
\hline $\begin{array}{l}\text { Además, es posible que haya un } \\
\text { historial familiar de consumo } \\
\text { de alcohol y drogas: la familia } \\
\text { está envuelta en estos proble- } \\
\text { mas sociales. Vemos esto, ¿qué } \\
\text { niños vemos? ¿De qué familias } \\
\text { son? Alcohol, drogas, pros- } \\
\text { titución. ¿De qué familias son? } \\
\text { De una madre que estaba en } \\
\text { un refugio. ¿De qué familias } \\
\text { son? Un niño o una niña que } \\
\text { fue criada por sus tíos, sus } \\
\text { tías, que no fue criada por sus } \\
\text { padres. O (un niño) que fue } \\
\text { criado por sus padres, pero } \\
\text { hubo incesto: hubo abusos } \\
\text { sexuales perpetrados por el } \\
\text { abuelo, el tío, el padre. Estas } \\
\text { son las cosas que vemos en su } \\
\text { historia familiar }\end{array}$ & $\begin{array}{l}\text { Also, there may be a family history } \\
\text { of alcohol and drug use- you } \\
\text { see (the family) is wrapped up } \\
\text { in these social problems. We see } \\
\text { this- what kids do we see? From } \\
\text { what families are they from? } \\
\text { Alcohol- drugs- prostitution. } \\
\text { From what families are they } \\
\text { from? From a mother who was } \\
\text { in a shelter. From what families } \\
\text { are they from? A boy or a girl } \\
\text { that was raised by their uncles, } \\
\text { their aunts, who was not raised } \\
\text { by their parents. Or (a child) } \\
\text { that was raised by her parents, } \\
\text { but there was incest- there } \\
\text { was sexual abuse perpetrated } \\
\text { by grandfather, the uncle, the } \\
\text { father. These are the things we } \\
\text { see in their family history }\end{array}$ \\
\hline
\end{tabular}

Several psychologists stated that environmental triggers of trauma in the migrant communities made hyperarousal especially pernicious at certain times of the day and days of the week. The typical informal sector work week in Peru is Monday through Saturday, thus starting Saturday evening through Monday morning the men in the community "come home." This coming home is tied to increased alcohol use and increased instances of IPV and child abuse (Kohrt BA et al. 2015; Kohrt BK et al. 2015). In addition, a lack of street lighting in the communities coinciding with the time of day that men leave work makes it difficult for women to identify who is coming towards them, causing increased hypervigilance at sundown. These triggers are mentioned below by Psychologists 5 and 3 respectively.

\begin{tabular}{ll}
\hline Sí, por ejemplo, tenía una & Yes, for example, I had a service \\
usuaria de 42 años quien tenía & user who was 42 years old that \\
una pequeña de siete años y & had a little 7-year-old daughter \\
una adolescente de 15. Me & and a 15-year-old daughter, and \\
decía, 'señorita cada vez que & she said to me- 'Miss- every \\
llega las siete de la noche, & night at 7:00, I just have too \\
tengo demasiado miedo, me & much fear-my hands shake- the \\
tiemblan las manos y lo único & only thing I do is get in my bed \\
que hago es meterme en la & and get under the covers. This is \\
cama y taparme... eso es lo & what I do every day at that time \\
que hago todos los días a esta & \\
hora.' & \\
Y si es sábado, cuando se & And if it's Saturday-when it gets \\
aproxima las $5: 00$ de la tarde, & to be about $5: 00$ in the after- \\
en media hora llegará (el hom- & noon- in half an hour they (the \\
bre) ... los niños comenzarán & men) will arrive... the children \\
a alborotarse y estarán todos & begin to get agitated and are \\
nerviosos. Este es un denomi- & all nervous. This is a common \\
nador común en nuestros & denominator in our service \\
usuarios & users
\end{tabular}

The effect of trauma on services users was described as leaving them "...never at peace" (Psychologist 7). The most commonly reported impacts were related to selfworth, identity, and goals (mentioned by 13 of the 15 psychologists) while the second most common was a decrease in interpersonal functioning (mentioned by 10 of the 15 psychologists). The belief that trauma changes your neurobiology, and that the brain and body are deeply implicated both in the experience of and treatment for trauma, was mentioned in each focus group. Only two psychologists mentioned that trauma affects a person's ability to experience, identify, and regulate emotions. The impact of trauma on one's identity can be seen in the quote below from Psychologist 7. 


\begin{tabular}{ll}
\hline Descubrí que ellas (las usuarias) & I've found that they (the service \\
no tienen objetivos, no tienen & users) do not have goals- they do \\
sueños. Viven para sus hijos: & not have objectives. They live for \\
cuando les entrevistas o & their children- when you do their \\
les dices: “CCuáles son tus & intake or say to them- "what are \\
sueños? ¿Tus objetivos a corto & your dreams? Your objectives- \\
y largo plazo? "Me dicen” & short and long term?” They say \\
Quiero que mi hijo sea un & to me "I want my child to be a \\
profesional, quiero que mi hijo & professional, I want my child to \\
sea feliz “." No. "Les digo. & be happy.” "No.” I say to them. \\
¿Cuáles son tus sueños?” & "What are your dreams?” They \\
en ese momento se quedan en & go blank \\
blanco &
\end{tabular}

Given that many initial traumas were perpetrated by family members, deep feelings of mistrust of parental figures was noted, as well as anger towards the nonoffending caregiver for not protecting the survivor. Many psychologists stated that this contributes to clients entering unhealthy relationships characterized by power and control. Every focus group mentioned blame and shame, stating that it was incredibly common for the service user to believe they caused their own trauma. Women carrying blame as part of living in a misogynistic society was mentioned frequently, and the fact that the system reiterates this blame was a significant barrier to treatment. One psychologist (Psychologist 6) stated, "shame and blame are the strongest weapons that society has against women."

When asked how they know someone is recovering, or "overcoming" trauma, the psychologists' responses mirrored the areas they identified as being affected by trauma; specifically, the most common types of responses were related to people demonstrating improved self-worth, a sense of personal identity, confidence, autonomy, and setting goals for their future, which often included attaining a job and other signs of social re-integration. Improved self-worth was often reflected in hygiene and dress, with most psychologists describing how the service users would suddenly start "arreglandose" or getting dressed and made up, as described below by Psychologist 8 .

\begin{tabular}{ll}
\hline Recuerdo que la vi llegar con & She arrived-I remember-with her \\
la nariz torcida, el hombre la & nose twisted and the man had \\
había agarrado así- y su brazo & grabber her like this- and her \\
.. y cuando hablaba, estaba & arm... and when she spoke, she \\
en shock, ¿no? iY después & was in shock, right... and then \\
verla cada semana con peque- & to see her each week get a little \\
nos arreglos en su apari- & better physically- right. Later \\
encia- bien!. Luego llega con & she came with her hair dyed \\
el cabello teñido y arreglado. & and done, and now I see her on \\
Ahora la veo en Facebook y & Facebook, and she is this happy \\
es una mujer soltera y feliz, & single woman-I mean from \\
quiero decir, verla venir con & where she came with all this \\
todo ese miedo y terror a verla & fear and terror-to see her now \\
ahora tan segura... & so secure...
\end{tabular}

Improved social and interpersonal functioning was the second most common theme related to a client overcoming trauma, which included improved parenting abilities and readiness for romantic relationships. Signs of neurocognitive and behavioral recovery were also mentioned, including the ability to talk about the trauma in the past tense, reduced physiological response to triggers, reduced avoidance, and viewing their trauma as part of their story, but not as their identity. Several psychologists raised ideas regarding what could protect communities from developing symptoms following a traumatic event. Specifically, a connection with nature, living in a community with less urban crowding, and a strong faith in God were seen as factors buffering against traumatic stress.

\section{Treatment for Trauma}

The most common treatment modality was cognitive behavioral therapy (CBT), which was mentioned in five of the six focus groups and by 12 of the 15 psychologists. The use of family systems treatment for trauma, Eye Movement Desensitization and Response (EMDR) treatment, and Gestalt therapy were mentioned by two psychologists respectively; of note, EMDR training had been provided in Lima, and was not available in Trujillo. The most commonly cited treatment elements identified in the focus groups are summarized in Table 2 and compared to the results of most commonly identified elements from the literature. A handful of techniques not specifically mentioned in the literature were discussed within the focus groups. Specifically, two psychologists mentioned the use of story-based techniques, such as the use of fables and metaphor, and two psychologists highlighted the importance of psychoeducation around the sociocultural causes of violence and abuse.

Non-specific treatment factors, or dimensions shared across psychotherapies that includes the development of the therapeutic alliance and other unspecified helping variables that influence client outcomes, were mentioned less frequently. However, basic helping skills, collaborative goal setting, case management, and motivational techniques were referenced by four psychologists (notably, not by any CMHC psychologists). Specific basic helping skills mentioned included rapport building, active listening, empathy-promoting behaviors, open questions, and giving space for the person to "desahogarse" (vent). Collaborative goal setting and promoting client autonomy were mentioned by all of the psychologists from the domestic violence center, as described by Psychologist 10. 
Table 2 Treatment components in evidence-based practice (EBP) literature as compared to focus groups

\begin{tabular}{|c|c|c|c|c|}
\hline Component & $\begin{array}{l}\% \text { of EBPs using } \\
\text { component }\end{array}$ & $\begin{array}{l}\text { EBP literature } \\
\text { rank }\end{array}$ & $\begin{array}{l}\% \text { of psychologists } \\
\text { using component }\end{array}$ & $\begin{array}{l}\text { Focus group } \\
\text { rank }\end{array}$ \\
\hline \multicolumn{5}{|l|}{ Psychoeducation } \\
\hline Psychoeducation regarding trauma & 33 & 2 & 13 & 5 \\
\hline Psychoeducation regard healthy sexuality & 18 & 16 & 7 & 9 \\
\hline \multicolumn{5}{|l|}{ Behavioral strategies } \\
\hline Behavioral activation & 25 & 5 & 13 & 5 \\
\hline Relaxation & 25 & 5 & 40 & 1 \\
\hline Behavior management/parenting skills training & 24 & 8 & 0 & \\
\hline Creation of and exposure to trauma narrative & 22 & 10 & 0 & \\
\hline Problem solving & 21 & 12 & 27 & 3 \\
\hline Safety planning & 19 & 13 & 0 & \\
\hline \multicolumn{5}{|l|}{ Interpersonal strategies } \\
\hline Identifying \& eliciting familial support & 19 & 13 & 13 & 5 \\
\hline Sharing trauma narrative & 19 & 13 & 0 & \\
\hline Identifying \& eliciting peer support & 13 & 22 & 33 & 2 \\
\hline Communication skills & 13 & 22 & 0 & \\
\hline Assessing relationships & 13 & 22 & 0 & \\
\hline Learning healthy sexuality & 10 & 25 & 0 & \\
\hline Improving child/caregiver relationship & 6 & 26 & 0 & \\
\hline \multicolumn{5}{|l|}{ Emotional techniques } \\
\hline Emotion regulation & 40 & 1 & 0 & \\
\hline Grounding techniques & 28 & 3 & 7 & 9 \\
\hline Identifying/eliciting affect & 16 & 18 & 7 & 9 \\
\hline Linking affect to events & 15 & 19 & 7 & 9 \\
\hline \multicolumn{5}{|l|}{ Cognitive techniques } \\
\hline Identifying \& restructuring thoughts (general) & 38 & 3 & 20 & 4 \\
\hline Insight building & 25 & 5 & 7 & 9 \\
\hline Identifying and re-structuring trauma-spec thoughts & 24 & 8 & 13 & 5 \\
\hline Self-talk & 22 & 10 & 0 & \\
\hline Distraction & 18 & 16 & 0 & \\
\hline Mindfulness & 15 & 19 & 0 & \\
\hline
\end{tabular}

\begin{tabular}{ll}
\hline Los usuarios vienen y dicen: & The service users come and say, \\
"Señorita, ayúdame". Pero en & 'Miss, help me.' But it is not \\
realidad no es así. Me he acos- & really like that. I have gotten \\
tumbrado a decir siempre en & used to always saying in the first \\
la primera sesión: "Usted es & session- 'You are the one who \\
quien puede tomar la decisión. & can make the decision. You are \\
Tú eres quien habla por ti. Yo & who speaks for you. I am here to \\
estoy aquí para apoyarle". & support you.' I always add 'We \\
Y siempre agrego" Estamos & are here to accompany you with \\
aquí para acompañarte en & this difficult situation, because \\
esta difícil situación, porque & we are both going to look for \\
ambos buscaremos estrategias & strategies that help you over- \\
que te ayuden a superar esta & come this difficulty or problem \\
dificultad o problema que está & that you are experiencing.' \\
pasando" & \\
\hline
\end{tabular}

\section{Barriers to Treatment}

Themes related to barriers to providing high quality trauma treatment fell into the areas of sociocultural barriers, clientencountered barriers, and provider-encountered barriers; these are summarized below.

\section{Sociocultural Barriers}

One frequently identified barrier was related to norms of monitoring and safety within the community. Specifically, it is common in these areas for children to be left alone with older siblings, cousins, neighbors, or non-blood relatives (e.g. step-fathers) while primary caregivers are working. Combined with a lack of education about sexual health and rights, high alcohol use amongst men, and machismo, this can often lead to young girls, and at times boys, being 
victimized by the same individuals who are supposed to be caring for them. This inability to provide safety for their clients prevented many providers from treating interpersonal trauma, as shared by Psychologist 14 .

\begin{tabular}{ll}
\hline Normalmente los niños se & $\begin{array}{l}\text { Usually the children stay home } \\
\text { alone. And where do you think }\end{array}$ \\
dónde crees que encontramos & we find the person who abused \\
a la persona que los maltrató? & them? Inside of the familial \\
Dentro del ambiente familiar, & environment- be it a neighbor, \\
ya sea un vecino, un tío o un & an uncle, or a grandfather. \\
abuelo. Imagine a un niño: ven & Imagine a child- they see the \\
a la figura paterna o al abuelo & father figure or grandfather as a \\
como una fuente de protec- & source of protection, and there \\
ción, y hay un apego a esa & is an attachment to that person. \\
persona. Nosotras no sabemos & We don't really know what \\
realmente qué intenciones & intentions this adult has- and \\
tiene este adulto, y quizás los & maybe the parents dedicate their \\
padres dedican su tiempo a & time to working because of their \\
trabajar debido a su situación & economic situation- so they can \\
económica, para que puedan & bring something home. What \\
llevar algo a casa. ¿Qué pasa & happens with these children \\
con estos niños-as, cuando & when no one is watching? \\
nadie está vigilando? & \\
\hline
\end{tabular}

Connected to this barrier were factors related to urban migration and overcrowding. As discussed previously, many service users in this region are from the northern Andes of Peru, where there is a higher percentage of indigenous persons, a tendency for more conservative beliefs, and a norm of not verbalizing individual suffering if it will affect familial well-being. When these families migrate to urban areas, they are constrained to small spaces with no physical barriers between rooms due to economic limitations and government squatting policies. The combination of these sociocultural and physical factors can increase risk for interpersonal abuse, as explained by Psychologist 15 .

\begin{tabular}{|c|c|}
\hline $\begin{array}{l}\text { El problema es que a veces no } \\
\text { pueden separar espacios, los } \\
\text { niños no tienen su propia hab- } \\
\text { itación, los padres tampoco, } \\
\text { todos están en un solo espacio. } \\
\text { Los hermanos mayores con la } \\
\text { hermana menor y con otros } \\
\text { miembros de la familia, esta es } \\
\text { una situación cultural porque } \\
\text { vienen del interior del país, } \\
\text { sea sierra y/o selva. En estas } \\
\text { áreas no se acostumbra a tener } \\
\text { sus propios espacios, todo } \\
\text { es en conjunto. Y todos ven } \\
\text { todo lo que pasa- tal vez están } \\
\text { imitando lo que ven }\end{array}$ & $\begin{array}{l}\text { The problem- is that sometimes } \\
\text { they can't separate themselves- } \\
\text { the children don't have their own } \\
\text { room- the parents don't have } \\
\text { their own room- everyone is in } \\
\text { one room. The older brothers } \\
\text { with the younger sister- other } \\
\text { family members- this is a } \\
\text { cultural situation because they } \\
\text { come from the mountains. In } \\
\text { the mountains they don't have } \\
\text { their own spaces- everything is } \\
\text { just together. And everyone sees } \\
\text { everything... maybe they just } \\
\text { imitate what they see }\end{array}$ \\
\hline
\end{tabular}

In addition, psychologists working primarily with women in situations of violence stated that the lack of collaboration and "misogynist tendencies" by the police compromised their ability to provide patients with the physical safety and support needed to be able to engage in meaningful

therapeutic work. These psychologists reported that their female service users do not feel they can report partner violence or refuse sex. Psychologist 9 describes how women are restricted from financial independence, which can trap them in situations of violence.

\begin{tabular}{cc}
\hline Además, el Perú es una sociedad & Also, Peru is a male chauvinist \\
muy machista. La pobreza es & society. The poverty is funda- \\
fundamental para la causa de & mental to the cause of (domestic \\
(violencia doméstica) porque & violence) because the women \\
las mujeres no tienen trabajo. & don't have jobs. The man gener- \\
El hombre genera el ingreso & ates the income. So, everything \\
económico. Entonces, todo & depends on what the man says- \\
depende de lo que él diga & what the man does- he has the \\
y haga, él tiene la última & say, really, right? She has no \\
palabra, ¿verdad? Ella no & economic independence \\
tiene independencia económica &
\end{tabular}

This systemic machismo meant that many women were ambivalent about reporting abuse, which could lead to episodes of verbal hostility against providers by the women or their families. Insufficient enforcement of laws and policies to protect clients was mentioned frequently; while laws against IPV and child maltreatment exist, the process is lengthy and often interrupted by strikes, administration changes, or other bureaucratic procedures. Blaming of the survivor by the police or court system was also frequently discussed as a barrier to helping their clients attain safety, justice, and peace of mind, as exemplified below by Psychologists 13 and 8 respectively.

He sido testigo de un caso de abuso psicológico y sexual de una niña, quien quedó embarazada por su propio padre. Pasó por todo el proceso legal y el hombre- padre de la niña, quedó libre. Él volvió a la casa. La niña era la hija más pequeña, tenía diez años. En casa también había otra niña, de unos 12 ó 14 años. Observar el peligro que había allí, y las leyes no son estrictas con estos casos, no como deberían ser

Lo peor de todo es que hay mujeres-hemos tenido mujeres que van a la estación de policía- comisaría, y la propia policía se burla de ellas. Se ríen diciendo “ ¿quién dejó la puerta abierta? ¿Por qué lo dejaste entrar?
I witnessed a case of psychological and sexual abuse of a girl who was impregnated by her own father. They went through the whole process and the manthe father of the girl- went free. And went back to the home. The girl was the youngest daughtershe was ten years old. There was another daughter in the home- she was 12 or 14. Look at the danger-the laws aren't strict how they should be

The worst of it all is that there are women- we have had women that go to the police station- and the police themselves mock her. They mock her, saying 'who left the door open? Why did you let him in?' 


\section{Client-Encountered Barriers}

Service users needing to work, and thus not being able to attend within a center's hours, was mentioned frequently. In addition, many clients' schedules were constantly changed by shift work managers, making scheduling and childcare additional barriers to keeping appointments. Treatment is free in all the centers involved in the study, but money to get to the center via public transit was often scarce and many survivors felt they could not justify the cost of weekly treatment due to lack of family support for mental health care. Psychologists also noted that the ongoing nature of trauma that many clients experienced made therapy less effective, as they often felt that small gains made in therapy were quickly swept away by the re-occurrence of violence, victimization, or abuse.

\section{Provider-Encountered Barriers}

Systematic barriers related to the mental health system were frequently identified as affecting treatment efficacy. This included the fact that most psychologists were on government contracts that had to be renewed annually; each year there was potential that they could be let go. This lack of stability made it difficult for them to advocate for their clients' needs. Budget cuts or misuse of funds by ministry officials sometimes meant that psychologists were forced to take unpaid, month-long vacations when money ran out, leaving only 1-2 of the staff psychologists active; active psychologists were expected to pick up their colleagues' caseloads, exacerbating the workload burden.

The Ministry of Health also demanded remarkably high caseloads, with some individuals required to see 16 patients in a seven-hour shift. This was not the case across centers; other psychologists were able to provide 40-60-min sessions, but this inconsistency resulted in significant frustration amongst psychologists interviewed. Psychologists also reported that the Ministry of Health dictated how many sessions a client could have, which often meant treatment was discontinued before it was really completed. This is described below by Psychologist 2 .

\begin{tabular}{lc}
\hline El tiempo que dan para una & The time they give you for a \\
consulta psicológica sólo da & psychological consult is just \\
tiempo para decir, “ ¿Hola & enough to say- 'Hi, how are you, \\
cómo estas, duermes mal, & are you sleeping poorly, are you \\
duermes bien?”, necesitas 50 & sleeping ok? Do you need $50 \mathrm{~g}$ \\
gramos de Acepango y chao & of Acepango, and bye.'
\end{tabular}

Physical infrastructure of the mental health centers was also mentioned frequently as a barrier to care. Psychologists mentioned how they often share offices, at times attending to service users simultaneously. Offices are often loud, and other staff or service users will knock or interrupt sessions.
Psychologists stated that insufficient resources for case management services, such as the ability to conduct home visits, is a barrier to treatment retention. Some providers demonstrated their own lack of motivation and potential stigma towards mental health problems, stating that individuals not wanting to change was a significant barrier to treatment efficacy, or stating that the environments that many clients live in are so chaotic that mental health treatment would not- and could not- be effective. A psychologist's personal difficulties, including life stressors or own histories of trauma or familial violence, were also mentioned as a potential barrier to the provision of effective treatment.

Of note, one of the barriers noted by multiple providers at the domestic violence center was related to how working there changed their identity and value system, which caused social isolation, conflict or ruptures with their romantic partners, and/or tension in their households. The psychologists stated that learning more about the causes of intimate partner violence motivated them to demand more equality in their own homes, and to educate their children in a way that reduced oppressive gender norms. Going against the cultural grain meant at times having to give up relationships or sacrifice close family ties, as described below by Psychologists 9 and 7 respectively.

\footnotetext{
Yo dije, "Pero ¿por qué tengo yo I said- 'but- why do I have to que llegar a la casa? ¿Por qué tengo que cocinar y lavarle la ropa a mi esposo? ¿Por qué debo mantener la casa limpia? Cuando él solo se ocupa de una sola cosa "trabajar" y eso es completamente normal. Pero así debe ser, dice él, así es la vida y así lo creo Dios. La mujer para la casa y el hombre para el trabajo. No hubo violencia ni física con él, pero esto era otro tipo de violencia. Cuando empecé a trabajar en la Defensoría entré en mi crisis personal, porque aquí descubrí nuevos conceptos y dije, "Estas mujeres, mis colegas, me están diciendo que lo que yo pienso no está mal, pero de donde vengo me dicen que está mal, que eso a Dios no le agrada. Aquí me dicen que no, que está mal. y ahí ya empezó el pleito y el problema con mi esposo. El dice "No eras así" Le digo, "Yo estoy", "No, pero es que yo pongo", como decir, "Yo

\author{
come home? Why do I have to \\ cook and hang my husband's \\ clothes? Why do I have to keep \\ the house clean? He only does \\ one thing-work- and that is \\ totally normal. 'But that is how \\ it should be (he says)- this is \\ life, and this is how God made \\ it. The woman for the home and \\ the man for work. There wasn't \\ physical violence with my hus- \\ band, but this is another kind of \\ violence. When I started work- \\ ing at the Defensoria, I entered \\ in a personal crisis, because \\ these were new concepts and I \\ said- 'these women (my cowork- \\ ers) are telling me that that what \\ I think isn't so crazy- but in my \\ home they say it is- that what I \\ think is unpleasing to God, but \\ here they tell me it's not so bad- \\ and this is where the problems \\ started with my husband. He \\ said, 'you are not like- like \\ them.' I said to him- 'Yes, I am.' \\ He says, 'but I provide.' As if \\ to say 'I pay-you eat because I \\ give you food, woman.'
} pago. Tú comes porque yo te doy mujer." 
De pronto un día le dices a tu familia, "Hoy no voy a servir la comida, ahí está sírvansela", "Qué cosa te está pasando", empiezan a decir, "Sal de ese trabajo", te están lavando la cabeza
Suddenly one day you say to your family- 'today I am not going to serve the food. There it is. Serve yourselves.' 'What is happening to you?' they start to say, 'leave that place-they are brainwashing you.'
Finally, a lack of training in trauma-focused therapies was mentioned as a barrier to effective treatment, as was access to curriculum appropriate for their context and culture. In terms of desired training, psychologists reported wanting to learn specific techniques for treating trauma and related symptomatology. Techniques specific to working with children, women in situations of violence, and with residential staff, the neurobiology of trauma, motivating clients, and assisting with re-integration into society were mentioned as key training targets.

\section{Discussion}

Migrant districts that surround Trujillo, Peru host some of the highest documented rates of IPV in the entirety of Latin America, as well as high rates of child maltreatment. However, mental health clinicians working in these districts do not have the resources, training, or structural support to effectively address interpersonal trauma in their communities. Given the dearth of applicable research on Latin American contexts, the use of qualitative focus groups was a critical step to the development of a contextually-grounded training in trauma treatment. The current study provides insight into the type of trauma experienced by service users in these communities, the structure of the new community mental health system, the training needs of psychologists addressing trauma, barriers to implementing effective treatment, and considerations for how current treatment methods fit with the evidence base.

As hypothesized, most traumas seen in these communities fall into complex and/or interpersonal traumas, with intimate partner violence and child physical and sexual abuse being the most commonly reported types of trauma. The psychologists' definition of trauma and recovery did not vary significantly from western definitions. However, while many U.S.based treatments focus on symptom reduction, development of emotion regulation skills, a reduction in maladaptive coping strategies, and reduced reactivity to trauma triggers as indicators of recovery, the participants stated that recovery in their communities was characterized by increased selfworth, knowing their legal rights, employment, improved interpersonal functioning, and breaking maladaptive relationship patterns. Given that complex trauma in these communities is nested within poverty and exclusion by the government, the need for individuals to have a powerful sense of agency, identity, and interpersonal competence is likely crucial to their success. Instruction in techniques to help bolster said areas will be a key area of training.

The present study also helped to inform training content and potential adaptations of EBPs. While the literature on efficacious treatments for the treatment of trauma spans a variety of modalities, a triphasic treatment model is a common thread across approaches. First outlined by Judith Herman, this treatment model proceeds through three stages: 1) safety and stabilization, 2) remembrance and mourning, and 3) reintegration (Herman, 2015). The following paragraphs discuss how this model can be adapted for the target population.

\section{Stage 1: Safety and Stabilization}

In the first phase of trauma training treatment, the therapist's goal is to help the client achieve a sense of physical and psychological safety and stability (Briere and Scott 2014; Herman 2015). Given the feedback in the focus groups, physical safety is not something that psychologists will be able to assume when someone presents for treatment. Many psychologists spoke about barriers to safety, including a lenient justice system, a misogynistic culture of blaming women by the police and other authorities, and economic dependence on the perpetrators, all of which reduce the likelihood that violence and abuse will be reported or prosecuted. In addition, the presence of intergenerational trauma nested within these sociocultural dynamics can result in mothers disbelieving their children's report of interfamilial abuse due to the potential for their own re-experiencing, limiting their ability to act as protectors of child survivors. Similarly, a primary goal of this phase is to reduce the fear and autonomic arousal one experiences when faced with trauma triggers. However, in this environment, some hypervigilance could be adaptive. Thus, necessary training considerations include how to help the client attain physical safety without justice system involvement and different treatment targets if the perpetrator continues to have contact with the survivor.

Psychological safety is another key component of this phase, which begins with the intentional development of the therapeutic relationship, building client autonomy and motivation, collaborative goal setting, and psychoeducation about the type of trauma the person is experiencing. Specific skills utilized in this phase include relaxation and anxiety reduction techniques, emotion identification and regulation, and identification and restructuring of thoughts (Briere and Scott 2014; Herman 2015). The psychologists in this study appear to be well-versed in the use of relaxation as well as in the basic tenets of CBT, thus more focus will likely be needed on integrating techniques specific to complex trauma, including the management of hyper- and hypo-arousal. In addition, given the Peruvian mental health 
system's general gravitation to a more authoritative approach to care, integration of basic helping skills and motivational interviewing techniques may be indicated.

\section{Stage 2: Remembrance and Mourning}

The second stage of treatment focuses on processing specific traumatic memories that alter the thoughts, feelings, and behavior of the person, especially the way they see themselves, others, and the world (Herman 2015). This often includes the creation of, exposure to, and re-processing of a trauma narrative. The use of a narrative was not mentioned by any psychologists; thus, this will be a primary skill introduced in the training. The training will also review how to use narrative techniques that draw out moments of strength and resilience to improve self-concept and create hope, such as the life timeline approach of narrative exposure therapy (Robjant and Fazel 2010). Without the focus on past successes, the sheer number of traumas experienced by many clients could result in their becoming depressed or hopeless during this phase or could exacerbate dissociative symptoms (Greenwell and Cosden 2009).

It is important to consider that most EBPs also include the sharing of a trauma narrative with a caregiver, family member, or other survivor as an additional step of exposure and support-seeking. For many children in this community, their caregivers may be their perpetrators, or may be protecting their perpetrators due to family loyalties and intergenerational trauma. Thus, the ability for a caregiver to hear, believe, and support a child should not be assumed. This is not to say that narrative sharing cannot occur, but creative approaches around who to share to will be necessary, and more time spent preparing the "listener" in how to bear witness without judgement.

\section{Stage 3: Reconnection}

The third phase of treatment focuses on helping a person integrate the trauma history into a larger holistic view of the self (Briere and Scott 2014). The goals of this phase are reconnection with social supports, friendships, and personal goals. Many of the psychologists discussed how service users did not have their own goals and were not sure of their identities outside of being a wife or mother. While part of this is normative and positive culturally, psychologists hoped to help service users learn to utilize their skill sets to build autonomy. In addition, many service users are separated from extended family and natural support systems. For example, religion was identified as a protective factor against developing traumatic stress, yet many of the migrants are Evangelicals, and may not be able to find a church of their denomination in Trujillo (Kohrt BA et al. 2015; Kohrt BK et al. 2015). A focus on realistic targets for reconnection with the community, and innovative ways to integrate spiritual resources, will be crucial factors to consider.

Further, when working with interpersonal traumas, this last phase includes revisiting norms, rights, and preferences related to intimate relationships and sexuality (Herman 2015). Cultural taboos in Andean Peru around discussing sexuality openly will require consideration around how to best provide education on a person's rights without violating cultural norms; this should be done in consultation with local churches, education centers, and mental health professionals. Similarly, one of the surprising findings from the domestic violence center focus group was that once the staff themselves learned more about gender role stereotypes as a mechanism of power and control, they struggled to fit in with their families and began to have conflict with partners. One psychologist even left her church and divorced her husband. While none of the psychologists regretted these decisions, given the stigma around both receiving and providing mental health care, it will be important to address relationships and sexuality in a way that does not ostracize the service users or service providers from their support systems.

\section{General Considerations for the Adaptation of Training Content}

In addition to the adaptations to the phasic model, there are certain factors related to the infrastructure of mental health care in the urban migrant communities that will affect our ability to train providers in EBPs without significant modification. The first barrier is related to the community mental health treatment packages. The treatments identified in the literature range from eight sessions to multi-year treatment, with the majority clustering around 12--24 sessions in addition to some type of skills group or peer support group, especially in the case of complex trauma. In the target region for this capacity building project, only patients with severe mental illness (SMI) diagnoses would be able to attend that many sessions; those presenting specifically for violence and maltreatment are typically only provided with five sessions. While some centers appear to have flexibility in asking for another treatment "package," this was not universal. We may consider discussing each phase of treatment as its own package, with the goal of increasing client retention by encouraging initial commitment to smaller numbers of sessions while developing safety and stability.

Further, two factors related to the mental health practitioners themselves should be considered based on the findings of this study. First, several responses within the focus groups suggested the presence of mental health stigma within providers, especially toward migrants from Andean Peru. Recent literature suggests that many mental health professionals, especially in low-resource contexts, endorse beliefs that clients with mental illness are dangerous, difficult to treat, and incapable 
of productivity or autonomy (Corrigan et al. 2014; Cusack et al. 2016). Such beliefs have been found to negatively affect mental health access, the quality of treatment, and therapeutic outcome (Lauber et al. 2006). Higher levels of stigma have also been tied to higher levels of staff burnout, and recent work examining mental health integration into medical settings in LMICs have found trainings to be less effective when provider stigma is not directly targeted (Gibb et al. 2010; Kohrt et al. 2018). Thus, it will be important within our capacity building model to intentionally measure and aim to reduce provider stigma. Second, individuals working with complex trauma understandably experience high rates of compassion fatigue and are susceptible to secondary trauma, with this phenomena being even more likely for service providers embedded within systems that fail to protect the survivor as was commonly cited in the focus groups (Craig and Sprang 2010). A handful of psychologists also spoke about their own trauma, history of violence, and "personal problems" as inhibiting their ability to serve this population, thus specific discussion around strategies for managing compassion fatigue and secondary trauma should be included.

\section{Limitations}

One of the primary limitations of this study is sample size; we spoke with only 15 psychologists, which limits the generalizability of findings. However, given that our goal is to create a training that is as grounded in the target community as possible, limiting participants to those serving the urban migrant community was prioritized over a larger sample size of mental health professionals in Trujillo in general. Another important limitation is related to foreigner status and privilege. Many parts of Peru are marked by colorism, with a tendency to view lighter-skinned individuals, and individuals from the Northern hemisphere, as having more authority and education (Golash-Boza 2010; Norwood 2013). This may have affected the way the primary author was perceived, which may have altered the responses provided within the focus groups. Further, in an attempt to increase access to EBPs for psychologists in this region, it is important to acknowledge that the literature for trauma is disproportionately conducted in high-income countries, thus our attempt to embed a training into this framework will be undoubtedly biased by western views of scientific evidence and efficacious treatment. It is our hope that the use of participatory methods and intentional crosscultural adaptation techniques will help mitigate some of these limitations.

\section{Conclusions and Future Directions}

Training of mental health professionals is scarcely discussed in the global mental health capacity building literature; thus, the present study provides some insight into how to shape this process. The new community mental health system in Northern Peru provides an exciting opportunity for capacity building of service providers, while high rates of complex and interpersonal trauma, and lack of training in this area, suggest that focusing on trauma is an important initial capacity building target. While a phase model can be used, it will require significant sociocultural and contextual adaptations, and authors must iteratively consider how their own privilege and background shape the training content and evaluation of success. The next step of this study is to design the capacity building model, which will be completed in close collaboration with cultural informants and local providers, and will be approved by the local Ministry of Health prior to the training.

Further, the present project focuses on the treatment of complex and interpersonal trauma after it happens, but as can be seen in the findings from the focus groups, there are a number of sociocultural factors that suggest that interpersonal violence and child maltreatment, especially child sexual abuse, and especially perpetrated amongst girls and women- will continue at an alarming rate. Thus, it will be important in the future to turn attention towards preventative measures related to gender-based violence (GBV). Research on reducing GBV states that changing attitudes is crucial towards changing behaviors, and recommend two primary prevention types: (1) small group, participatory workshops that build prosocial skills, encourage personal reflection and debate, and promote collective action, and (2) "edutainment" efforts that focus on radio, theater, and tv campaigns (Ellsberg et al. 2015; Heise 2011). There are a handful of programs, including Program H/Program $M$ in Brazil, and Stepping Stones in South Africa, that have been successfully integrated these types of programs into the public school system and community. Both programs have been effective in helping boys and young men shift strict gender attitudes that contribute to gender-based violence, and preliminary findings also show a moderate reduction in GBV (Barker et al. 2010; Gibbs et al. 2015; Ricardo et al. 2010). A consideration of how similar programs could be used in Peru is an important future direction.

Finally, a significant barrier to reducing repeated violence is related to a lax justice system and misogynist attitudes amongst law enforcement, a significant factor seen in the current study. An additional prevention of revictimization approach should include direct sensitization work with local authorities. Models that focus on meaningful 
interactions between service users/survivors and authorities, such as the Crisis Intervention Team (CIT) model developed in the U.S. but successfully adapted in Liberia (Kohrt BA et al. 2015), could be useful for addressing the safety, security, and trust gaps experienced between survivors of interpersonal violence and the people charged with protecting them within the migrant communities in Northern Peru.

\section{Compliance with Ethical Standards}

Conflict of interest The authors declare that they have no conflict of interest.

Ethical Approval Ethical approval for this study was obtained from the Institutional Review Board of the University of Denver (reference 1140817-3), and from the Ministry of Health in Trujillo (La Libertad). All authors read and approved the final manuscript and certify responsibility.

Informed Consent Informed consent was obtained from all individual participants included in the study. All participating psychologists were asked to review the veracity of their statements and comfort with publication prior to inclusion.

\section{References}

Barker, G., Ricardo, C., Nascimento, M., Olukoya, A., \& Santos, C. (2010). Questioning gender norms with men to improve health outcomes: Evidence of impact. Global Public Health, 5(5), 539-553.

Bisson, J. I., Roberts, N. P., Andrew, M., Cooper, R., \& Lewis, C. (2013). Psychological therapies for chronic post-traumatic stress disorder (PTSD) in adults. Cochrane Database of Systematic Reviews, (12).

Bohus, M., Dyer, A. S., Priebe, K., Kruger, A., Kleindienst, N., Schmahl, C., ... Steil, R. (2013). Dialectical behaviour therapy for post-traumatic stress disorder after childhood sexual abuse in patients with and without borderline personality disorder: A randomised controlled trial. Psychotherapy and Psychosomatics, 82(4), 221-233 https://doi.org/10.1159/000348451

Briere, J. N., \& Scott, C. (2014). Principles of trauma therapy: A guide to symptoms, evaluation, and treatment (DSM-5 update). Thousand Oaks, CA: Sage Publications.

Corrigan, P. W., Mittal, D., Reaves, C. M., Haynes, T. F., Han, X., Morris, S., et al. (2014). Mental health stigma and primary health care decisions. Psychiatry Research, 218(1-2), 35-38.

Craig, C. D., \& Sprang, G. (2010). Compassion satisfaction, compassion fatigue, and burnout in a national sample of trauma treatment therapists. Anxiety, Stress, \& Coping, 23(3), 319-339.

Cusack, K., Jonas, D. E., Forneris, C. A., Wines, C., Sonis, J., Middleton, J. C., ... Greenblatt, A. (2016). Psychological treatments for adults with posttraumatic stress disorder: A systematic review and meta-analysis. Clinical Psychology Review, 43, 128-141

Defensoría Municipal del Niño y el Adolescente de la Municipalidad Provincial de Trujillo., (2014). Demuna elaboró 10,623 expedientes para atender derechos de niños. Trujillo, Peru: Author.

Eaton, J., McCay, L., Semrau, M., Chatterjee, S., Baingana, F., Araya, R., ... Saxena, S. (2011). Scale up of services for mental health in low-income and middle-income countries. The Lancet, 378(9802), $1592-1603$

Ellsberg, M., Arango, D. J., Morton, M., Gennari, F., Kiplesund, S., Contreras, M., et al. (2015). Prevention of violence against women and girls: what does the evidence say? The Lancet, 385(9977), $1555-1566$.

Foa, E. B., McLean, C. P., Capaldi, S., \& Rosenfield, D. (2013). Prolonged exposure vs supportive counseling for sexual abuse-related PTSD in adolescent girls: A randomized clinical trial. JAMA, 310(24), 2650-2657.

Gibb, J., Cameron, I., Hamilton, R., Murphy, E., \& Naji, S. (2010). Mental health nurses' and allied health professionals' perceptions of the role of the occupational health service in the management of work-related stress: How do they self-care? Journal of Psychiatric and Mental Health Nursing, 17(9), 838-845.

Gibbs, A., Jewkes, R., Sikweyiya, Y., \& Willan, S. (2015). Reconstructing masculinity? A qualitative evaluation of the stepping stones and creating futures interventions in urban informal settlements in South Africa. Culture, Health \& Sexuality, 17(2), 208-222.

Gillies, D., Taylor, F., Gray, C., O’Brien, L., \& D'Abrew, N. (2013). Psychological therapies for the treatment of post-traumatic stress disorder in children and adolescents. Evidence-based Child Health: ACochrane Review Journal, 8(3), 1004-1116.

Golash-Boza, T. (2010). Does whitening happen? Distinguishing between race and color labels in an African-descended community in Peru. Social Problems, 57(1), 138-156.

Greenwell, A. N., \& Cosden, M. (2009). The relationship between fatalism, dissociation, and trauma symptoms in Latinos. Journal of Trauma \& Dissociation, 10(3), 334-345.

Heise, L. (2011). What works to prevent partner violence? An evidence overview.

Herman, J. (2015). Trauma and recovery: The aftermath of violence, from domestic abuse to political terror. New York, NY: Basic Books.

Jorm, A. F., Patten, S. B., Brugha, T. S., \& Mojtabai, R. (2017). Has increased provision of treatment reduced the prevalence of common mental disorders? Review of the evidence from four countries. World Psychiatry, 16(1), 90-99.

Kakuma, R., Minas, H., van Ginneken, N., Dal Poz, M. R., Desiraju, K., Morris, J. E., ... Scheffler, R. (2011). Human resources for mental health care: Current situation and strategies for action. The Lancet, 378(9803), 1654-1663

Kohrt, B. A., Blasingame, E., Compton, M. T., Dakana, S. F., Dossen, B., Lang, F., et al. (2015). Adapting the crisis intervention team (CIT) model of police-mental health collaboration in a low-Income, post-conflict country: Curriculum development in Liberia, West Africa. American Journal of Public Health, 105(3), e73-e80....

Kohrt, B. K., Barrueco, S., \& Pérez, C. P. (2015). Domestic violence as a threat to maternal and child well-being in an urban migrant community in Peru. Revista Panamericana De Salud Publica, $37,265-272$.

Kohrt, B. A., Jordans, M. J., Turner, E. L., Sikkema, K. J., Luitel, N. P., Rai, S., ... Patel, V. (2018). Reducing stigma among healthcare providers to improve mental health services (RESHAPE): Protocol for a pilot cluster randomized controlled trial of a stigma reduction intervention for training primary healthcare workers in Nepal. Pilot and Feasibility Studies, 4(1), 36-53

Lauber, C., Nordt, C., Braunschweig, C., \& Rössler, W. (2006). Do mental health professionals stigmatize their patients? Acta Psychiatrica Scandinavica, 113, 51-59.

Leenarts, L. E., Diehle, J., Doreleijers, T. A., Jansma, E. P., \& Lindauer, R. J. (2013). Evidence-based treatments for children with traumarelated psychopathology as a result of childhood maltreatment: A systematic review. European Child \& Adolescent Psychiatry, 22(5), 269-283. 
Naranjo Morales, A. G. (2007). The Peruvian migration phenomenon. Lima: Centro de Asesoria Laboral del Peru.

National Child Traumatic Stress Network. (n.d.). Complex trauma. Retrieved from https://www.nctsn.org/what-is-child-trauma/traum a-types/complex-trauma.

Norwood, K. J. (Ed.). (2013). Color matters: Skin tone bias and the myth of a postracial America. New York, NY: Routledge.

Pan American Health Organization. (2013). WHO-AIMS: Report on mental health systems in Latin America and the Caribbean.

Parkinson, S., Eatough, V., Holmes, J., Stapley, E., \& Midgley, N. (2016). Framework analysis: A worked example of a study exploring young people's experiences of depression. Qualitative Research in Psychology, 13(2), 109-129.

Patel, V., Saxena, S., Lund, C., Thornicroft, G., Baingana, F., Bolton, P., ... UnUtzer, J. (2018). The lancet commission on global mental health and sustainable development. Lancet, 392(10157), 1553-1598. https://doi.org/10.1016/S0140-6736(18)31612-X

Quijano Pacheco, J. (2017). Plan estratégico escuela de psicología 2013-2016. Lima, Peru: Author.

Ricardo, C., Nascimento, M., Fonseca, V., \& Segundo, M. (2010). Program $H$ and Program M: Engaging young men and empowering young women to promote gender equality and health. Washington, DC: Pan American Health Organization.
Rivera, S. (2008). Culturally-modified trauma-focused treatment for Hispanic children: Preliminary findings (Doctoral dissertation, ProQuest Information \& Learning).

Robjant, K., \& Fazel, M. (2010). The emerging evidence for narrative exposure therapy: A review. Clinical Psychology Review, 30(8), $1030-1039$.

Syros, I. (2017). Cognitive behavioral therapy for the treatment of PTSD. European Journal of Psychotraumatology, 8(sup4), 1351219.

Thornicroft, G., Chatterji, S., Evans-Lacko, S., Gruber, M., Sampson, N., Aguilar-Gaxiola, S., ... Borges, G. (2017). Undertreatment of people with major depressive disorder in 21 countries. The British Journal of Psychiatry, 210(2), 119-124

Toyama, M., Castillo, H., Galea, J. T., Brandt, L. R., Mendoza, M., Herrera, V., ... Diez-Canseco, F. (2017). Peruvian mental health reform: A framework for scaling-up mental health services. International Journal of Health Policy and Management, 6(9), $501-508$

Publisher's Note Springer Nature remains neutral with regard to jurisdictional claims in published maps and institutional affiliations. 